\title{
IMMUNOPRECIPITATION TECHNIQUES AND ELISA IN THE DETECTION OF ANTI-Fonsecaea pedrosoi ANTIBODIES IN CHROMOBLASTOMYCOSIS
}

\author{
Mônica Scarpelli Martinelli VIDAL(1), Luis Guilherme Martins de CASTRO(2), Sônia Cristina CAVALCANTE(1) \& Carlos da Silva LACAZ(1) ${ }^{\dagger}$
}

\begin{abstract}
SUMMARY
Chromoblastomycosis (CBM) is a chronic subcutaneous infection caused by several dematiaceous fungi. The most commonly etiological agent found in Brazil is Fonsecaea pedrosoi, which appears as thick walled, brownish colored cells with transverse and longitudinal division in the lesions, called "muriform cells". This disease is found worldwide but countries like Madagascar and Brazil have highest incidence. Diagnosis is made by clinical, direct and histopathologic examination and culture of specimens. Serological tests have been used to identify specific antibodies against Fonsecaea pedrosoi antigens, as well as immunotechniques have been used for CBM serological identification and diagnosis. In the present study double immunodiffusion (DID), counterimmunoelectrophoresis (CIE) and immunoenzymatic test (ELISA) have been used to evaluate humoral immune response in patients with CBM caused by $F$. pedrosoi. Metabolic antigen was used for immunoprecipitation tests (DID and CIE) while somatic antigen for ELISA. Our results demonstrated 53\% sensitivity and 96\% specificity for DID, while CIE presented 68\% sensitivity and 90.5\% specificity. ELISA demonstrated $78 \%$ sensibility and $83 \%$ specificity. Serological tests can be a useful tool to study different aspects of CBM, such as helping differential diagnosis, when culture of the pathogenic agent is impossible.
\end{abstract}

KEYWORDS: Chromoblastomycosis; Fonsecaea pedrosoi; Serologic tests and antigen.

\section{INTRODUCTION}

Chromoblastomycosis (CBM) is a chronic infection of skin and subcutaneous tissue caused by dematiaceous fungi. The causal agents are normally found as saphrophytes in soil and vegetation and infection follows traumatic implantation ${ }^{17}$.

The most important agent of CBM in Brazil is Fonsecaea pedrosoi. It can be considered endemic in certain regions ${ }^{1,3,4,13,22,24,27,28,29,30}$. Diagnosis is accomplished by clinical, direct and histopathologic examination and culture of specimens. The fungus appears in lesions as thick walled, brownish colored cells with transverse and longitudinal division, also known as "muriform cells" or "sclerotic cells" ${ }^{17}$.

Although serological tests are of great help in establishing diagnosis and helping monitorization of therapy of deep mycoses, they have not been routinely used for CBM. The first demonstration of specific circulating antibodies in $F$. pedrosoi-caused CBM was performed using conidia precipitation ${ }^{5}$. DID and CIE were used to analyze sera of CBM caused by Cladophialophora carrionii. It was demonstrated that metabolic antigens presented higher specificity and results depended on the use of fresh sera, since storage for long period (two years) causes looses or inactivation of the antibodies. These authors recommended the implantation of this methodology for routine immunodiagnosis of chromoblastomycosis based on the results and on the ease to perform the tests 32,33 .

The exoantigen test was used for serological identification of several dematiaceous fungi and it is considered a useful tool to distinguish CBM agents $^{8,13,21,23}$.

The ELISA has been extensively used to detect either antigens or antibodies in infectious diseases. Investigators from Madagascar ${ }^{2,9}$ reported the successful use of ELISA to study sera from human CBM cases, most of which caused by $F$. pedrosoi. They reported that ELISA test was reproducible, gave satisfactory results and allowed biologic diagnosis of CBM, even when culture of the pathogenic agent was not possible. ELISA, using somatic antigen from $F$. pedrosoi and C. carrionii reference strains, presented $87 \%$ sensitivity and $92.3 \%$ specificity. The same test was used to detect circulating antibodies in patients with $C$. carrionii-caused CBM. This test proved to be a useful tool for the differential serodiagnosis of this infection.

In the present study, the authors evaluated sensitivity and specificity of DID, CIE and ELISA in detecting anti- F. pedrosoi antibodies in sera of patients with CBM caused by this fungus. 


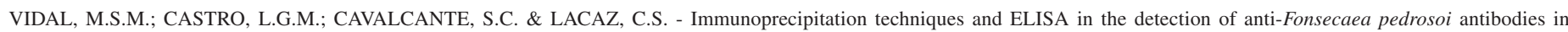
chromoblastomycosis. Rev. Inst. Med. trop. S. Paulo, 45(6):315-318, 2003.

\section{MATERIAL AND METHODS}

Sera: Sixty sera samples obtained from patients with CBM caused by $F$. pedrosoi and followed at the "Clínica Dermatológica do Hospital das Clínicas da Universidade de São Paulo, Brasil" were analyzed. Diagnosis was confirmed by the presence of sclerotic cells in lesions (direct exam) and growth of $F$. pedrosoi in culture. Hyperimmune serum was produced by inoculation of two New Zealand males, $3 \mathrm{~kg}$ in weight rabbits with $F$. pedrosoi metabolic antigen, according to GARCIA et al. ${ }^{12}$. Serum was precipitated by caprilic acid according to the methodology described by McKINNEY \& PARKINSON ${ }^{20}$. Sera from 36 sporothricosis (SPT) patients, 34 cutaneous leishmaniasis (CL) patients and 48 from healthy blood donors (HBD) were used as controls.

Metabolic Antigen (Met-Ag): Culture filtrate of F. pedrosoi sample \# 884 from Instituto de Medicina Tropical de São Paulo Collection was used to produce Met-Ag. This sample was cultured on Sabouraud-agar at $25{ }^{\circ} \mathrm{C}$ for 10 days. The inoculum was prepared in $0.85 \%$ saline, to reach McFarland's scale 5. Five $\mathrm{ml}$ of the suspension was incubated in $250 \mathrm{ml}$ of Sabouraud-broth at $25^{\circ} \mathrm{C}$ for 30 days, under constant shaking. Culture was killed by addition of thimerosal at 1:5000 and filtrated through Whatman paper \#1, according to VIDAL et al. ${ }^{31}$. The filtrate was concentrated (antigen) and maintained at $4{ }^{\circ} \mathrm{C}$ until use.

Somatic antigen (Som-Ag): Mycelial mats were washed in phosphate buffer solution (PBS) three times and mechanically disrupted using ice and glass bits. The suspension was left at $4{ }^{\circ} \mathrm{C}$ for two days followed by centrifuging at $3000 \mathrm{rpm}$ for 30 minutes, according to GARCIA ${ }^{11}$. The supernatant (antigen) was frozen at $-20^{\circ} \mathrm{C}$ until use. al. ${ }^{19}$.

Antigen protein content was determined according to LOWRY et

Double immunodiffusion (DID): Glass slides $(25$ X $75 \mathrm{~mm}$ ) were covered with $3 \mathrm{ml}$ of sodium citrate agar $1 \%$ and left at $4{ }^{\circ} \mathrm{C}$ for three hours. A seven-well template was stamped twice on the surface of each slide. Met-Ag was placed in the central well and sera samples in the surrounding six wells. The slides were incubated for 48 hours at room temperature and washed for further 48 hours using saline solution. A stove was used to dry the slides by evaporation. Slides were stained using $0.4 \%$ Coomassie Brilliant Blue (Sigma) in acetic acid 10\% solution. Precipitation lines indicated positivity.

Counterimmunoelectrophoresis (CIE): The same slides used for DID were covered with barbital-buffered agarose ( $\mathrm{pH}$ 8.2), to produce wells with $3 \mathrm{~mm}$ in depth. Thirteen $\mu \mathrm{l}$ of Met-Ag and sera were placed in the wells. The slides were submitted to electrophoresis with barbital buffer ( $\mathrm{pH} \mathrm{8.2),} 4$ volts/cm, for 90 minutes through filter paper. Gels were processed as described for DID.

ELISA: Indirect ELISA was performed according to DEL NEGRO et al. ${ }^{7}$. For standardization purposes different aspects were evaluated: a) Antigen concentration: Somatic antigen optimal protein concentration was found to be $2.5 \mu \mathrm{g} / \mathrm{ml}$, as demonstrated by dilution in carbonate/ bicarbonate buffer ( $\mathrm{pH} 9.6$ ); b) both positive and negative sera were used at 1:40 dilution (previously titrated) and each sample was analyzed in triplicate; c) Conjugate: a goat anti-human (reactive against IgG) peroxidase conjugate (Sigma) was diluted 1:700 (optimal concentration).
Each experiment was performed including a step with $1 \%$ Bovine Serum Albumine (BSA). Optical density (OD) was determined using a $490 \mathrm{~nm}$ filter. Cut off value was determined as the average OD of control sera added two standard deviations. d) Sensitivity and specificity were calculated on homologous (60 CBM) and heterologous (36 SPT, 34 CL and 48 HBD) sera samples, according to LINNET ${ }^{18}$.

\section{RESULTS}

Hyperimmune serum reacted both with Met-Ag by DID and CIE up to a 1:32 dilution. Met-Ag protein content was $4.90 \mathrm{mg} / \mathrm{ml}$ while for Som-Ag it was $0.70 \mathrm{mg} / \mathrm{ml}$. Hyperimmune serum showed $0.186 \mathrm{mg} / \mathrm{ml}$ protein content.

DID: $32(53 \%)$ out of $60 \mathrm{CBM}$ sera samples tested positive. Only 3 $(8.3 \%)$ of 36 SPT sera and $3(8.8 \%)$ out 34 CL sera tested positive. None of the 48 HBD sera tested positive. DID presented $53 \%$ sensitivity and $96 \%$ specificity.

CIE: $41(68 \%)$ out of $60 \mathrm{CBM}$ sera samples tested positive. Six (16.7\%) out of 36 SPT sera, $6(17.6 \%)$ out of 34 CL sera tested positive exclusively when undiluted sera samples were used. None of $48 \mathrm{HBD}$ sera tested positive. CIE presented $68 \%$ sensitivity and $90.5 \%$ specificity. Table 1 describes all values of sensitivity and specificity of the different tests, against the all sera sample groups studied.

ELISA: Figure 1 demonstrates results about ELISA. Cut-off value was determined as 0.122 OD (black line). ELISA tested positive in 45 CBM sera, 10 SPT sera, 8 CL sera and 3 HBD sera. This test showed $78 \%$ of sensitivity and $83 \%$ of specificity.

Table 1

Sensitivity and specificity results by tests

\begin{tabular}{lcc}
\hline Reaction & $\begin{array}{c}\text { Sensitivity } \\
(\text { CBM sera) }\end{array}$ & $\begin{array}{c}\text { Specificity } \\
\text { (SPT,CL and HBD sera) }\end{array}$ \\
\hline DID & $53 \%$ & $96 \%$ \\
& $(32 / 60)^{*}$ & $(06 / 118)^{*}$ \\
CIE & $68 \%$ & $90.5 \%$ \\
& $(41 / 60)^{*}$ & $(12 / 118)^{*}$ \\
ELISA & $78 \%$ & $83 \%$ \\
& $(45 / 60)^{*}$ & $(21 / 118)^{*}$ \\
\hline
\end{tabular}

*number of reagent sera / total number sera used. $\mathrm{CBM}=$ chromoblastomycosis; $\mathrm{SPT}=$ sporotricosis $; \mathrm{CL}=$ leishmaniasis $; \mathrm{HBD}=$ health blood donors; $\mathrm{DID}=$ double immunodiffusion; $\mathrm{CIE}=$ couterimmunoelectrophoresis.

\section{DISCUSSION}

Although serological tests are not routinely used for CBM diagnosis, numerous papers on this matter have appeared in the literature. A wide array of different dematiaceous fungi antigens is currently available for use in serologic tests $2,3,5,6,9,10,14,16,24,28,29$. The large experience using Met$\mathrm{Ag}$ in gel precipitation serologic tests for diagnosis of deep mycosis led us to test this type of antigen using DID and CIE. BUCKEY \& MURRAY $^{5}$, testing CBM Met-Ag by DID, demonstrated that almost all patients developed precipitating antibodies at some phase of the disease. 


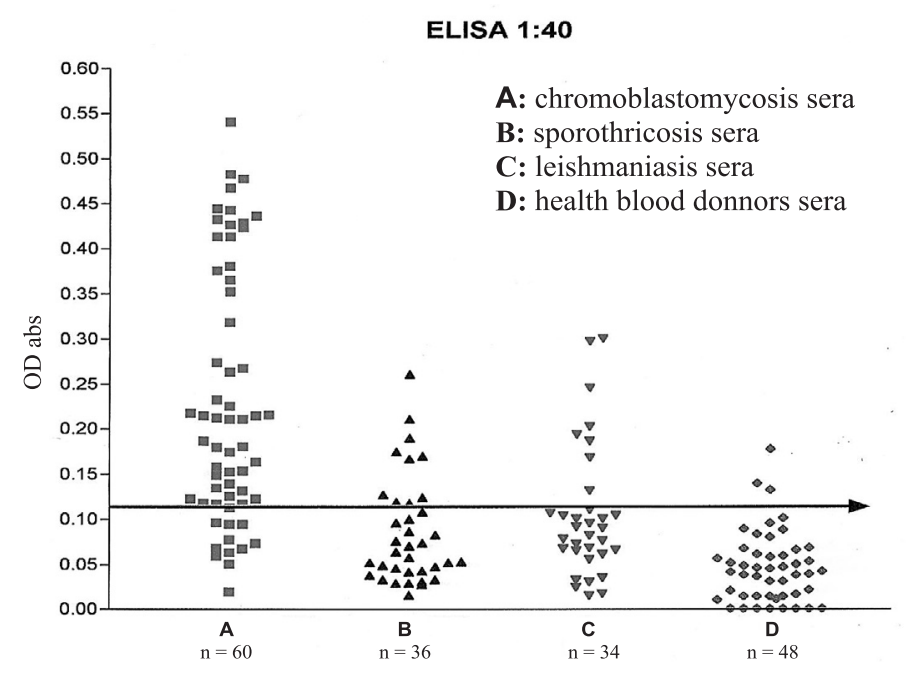

Fig. 1 - ELISA results. The black line demonstrated cut off $=0.122$ OD. $n=$ total number sera studied of the each group (CBM, SPT, CL and HBD)

VILLALBA \& YEGRES ${ }^{33}$ emphasized that precipitation reactions tend to present low sensitivity because of the low amount of circulating antibodies found in CBM. These authors also reported cross-reactivity with health controls' sera and SPT patients' sera, which accounted for low specificity, a finding also observed by ISHIZAKI et al. ${ }^{15}$, who studied hyperimmune anti-Sporothrix schenckii serum against different fungal antigens, including $F$. pedrosoi. VILLALBA ${ }^{32}$ testing Met-Ag by CIE demonstrated that this antigen presented higher specificity for F. pedroso $i$ than Som-Ag. ROMERO et al. ${ }^{26}$ evaluated sera samples of patients with CBM caused by Cladophialophora carrionii using DID and CIE. According to these authors DID presented higher specificity and sensitivity than CIE. In contrast, the present data showed that CIE presented superior sensitivity, but lower specificity.

In the present study ELISA was able to identify specific antibodies against $F$. pedrosoi Som-Ag in 45 (75\%) of 60 CBM sera. It was $78 \%$ sensitive and $83 \%$ specific. In 1993, ANDRIANTSIMAHAVANDY et $a l .{ }^{2}$ used ELISA to test sera of CBM patients from Madagascar. The authors used Som-Ag of both, F. pedrosoi and C. carrionii, the most prevalent species in the island. Based on $86 \%$ reproducibility and $65 \%$ specificity they concluded that ELISA, using F. pedrosoi and C. carrionii Som-Ag, was a satisfactory tool for biologic diagnosis of CBM. ESTERRE et al. ${ }^{9}$ used ELISA to analyse 136 sera samples obtained from $43 \mathrm{CBM}$ patients enrolled in a one-year therapeutic trial of terbinafine. Sensitivity reached $87 \%$ and specificity $92.3 \%$. ROMERO et al. ${ }^{27}$ evaluated ELISA test for CBM caused by C. carrionii in Venezuela using Som-Ag. Results were also encouraging ( $82.5 \%$ sensitivity and $81.8 \%$ specificity).

The data presented demonstrate that serological tests can be a useful tool to study CBM caused by F. pedrosoi specially when the culture of the pathogenic agent is not possible and on the basis of the results, the serological tests can be a useful tool to help a serological identification, immunological evaluate and monitoring the efficiency of treatment on CBM, after future studies. The identification of specific antigenic fractions is currently under investigation and results are promising.

\section{RESUMO}

\section{Técnicas de imunoprecipitação e ELISA na detecção de anticorpos anti-Fonsecaea pedrosoi na cromoblastomicose}

Cromoblastomicose (CBM) é infecção subcutânea causada por vários fungos demáceos. O agente mais importante no Brasil é Fonsecaea pedrosoi, que se apresenta nas lesões como células de coloração acastanhada, com divisão transversal e longitudinal, originando as denominadas "células muriformes". Esta infecção apresenta caráter universal, mas países como Madagascar e Brasil apresentam alta incidência. O diagnóstico é realizado através dos exames clínico, direto e histopatológico, acompanhado de cultura e identificação do agente etiológico. Os testes sorológicos foram aplicados para identificar anticorpos específicos frente a antígenos de Fonsecaea pedrosoi e várias metodologias têm sido empregadas para identificação sorológica e o diagnóstico da CBM. Neste estudo, avaliamos reações de imunodifusão dupla (DID), contraimunoeletroforese (CIE) e teste imunoenzimático (ELISA) para avaliar a resposta imune humoral na CBM causada por $F$. pedrosoi. Utilizamos antígeno metabólico para DID e CIE e antígeno somático para ELISA. Nossos dados revelaram 53\% e $68 \%$ de sensibilidade e $96 \%$ e $90,5 \%$ de especificidade, respectivamente. O teste de ELISA demonstrou $78 \%$ de sensibilidade e $83 \%$ de especificidade. Estes resultados indicam que as reações sorológicas podem ser uma ferramenta útil no auxílio diagnóstico desta infecção, quando a cultura do agente não for possível.

\section{REFERENCES}

1. ALEIXO, J. - Subsidio ao estudo da cromomicose. Belo Horizonte, 1946. (Tese de livre docência - Faculdade de Medicina da Universidade de Minas Gerais).

2. ANDRIANTSIMAHAVANDY, A.; MICHEL, P.; RASOLOFONIRINA, N. \& ROUX, J. - Apport de l'immunologie au diagnostic de la chromomycose a Madagascar. J. Mycol. méd., 3: 30-36, 1993.

3. BARROS, T.F. \& RESENDE, M.A. - Partial chemical characterization of antigenic preparation of chromoblastomycosis agents. Rev. Inst. Med. trop. S. Paulo, 41: 343-350, 1999.

4. BOPP, C. - Cromoblastomicoses: contribuição ao estudo de alguns de seus aspectos. Porto Alegre, Livraria do Globo, 1959. (Tese de cátedra - Faculdade de Medicina da Universidade do Rio Grande do Sul).

5. BUCKLEY, H.R. \& MURRAY, I.G. - Precipitating antibodies in chromomycosis. Sabouraudia, 5: 78-80, 1966.

6. COOPER, B.H. \& SCHNEIDAU, J.D. - A serological comparison of Phialophora verrucosa, Fonsecaea pedrosoi and Cladosporium carrionii using immunodiffusion and immunoelectrophoresis. Sabouraudia, 8: 217-226, 1970.

7. DEL NEGRO, G.M.B.; PEREIRA, C.N.; ANDRADE, H.F. et al. - Evaluation of tests for antibody response in the follow-up of patients with acute and chronic forms of paracoccidioidomycosis. J. med. Microbiol., 49: 37-46, 2000.

8. ESPINEL-INGROFF, A.; SHADOMY, S.; DIXON, D. \& GOLDSON, P. - Exoantigen test for Cladosporium bantianum, Fonsecaea pedrosoi and Phialophora verrucosa. J. clin. Microbiol., 23: 305-310, 1986.

9. ESTERRE, P.; JAHEVITRA, M.; RAMARCEL, A. \& ANDRIANTSIMAHAVANDY, A. - Evaluation of the ELISA technique for the diagnosis and the seroepidemiology of chromoblastomycosis. J. Mycol. méd., 7: 137-141, 1997. 


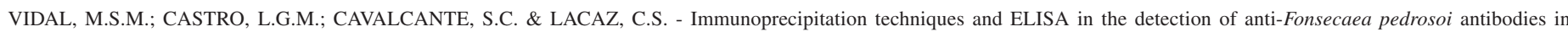
chromoblastomycosis. Rev. Inst. Med. trop. S. Paulo, 45(6):315-318, 2003.

10. ESTERRE, P.; JAHEVITRA, M. \& ANDRIANTSIMAHAVANDY, A. - Humoral immune response in chromoblastomycosis during and after therapy. Clin. Diagn. Lab. Immunol., 7: 497-500, 2000.

11. GARCIA, N.M. - Antigenemia no modelo murino isogênico da paracoccidioidomicose. São Paulo, 1995. (Dissertação de mestrado - Faculdade de Ciências Farmacêuticas da USP).

12. GARCIA, N.M.; ASSIS, C.M.; DEL NEGRO, G.M.B. \& LACAZ, C.S. - Obtenção de exoantígenos de Histoplasma capsulatum em meio de neopeptona, glicose, tiamina e asparagina (NGTA). Rev. Inst. Med. trop. S. Paulo, 32: 370-374, 1990.

13. HONBO, S.; PADHYE, A.A. \& AJELLO, L. - The relationship of Cladosporium carrionii to Cladophialophora ajelloi. Sabouraudia, 22: 209-218, 1984.

14. IBRAHIM-GRANET, O.; de BIÈVRE, C.; ROMAIN, F. \& LETOFFE, S. - Comparative electrophoresis, isoelectric focusing and numerical taxonomy of some isolates of Fonsecaea pedrosoi and allied fungi. Sabouraudia, 23: 253-264,1985.

15. ISHIZAKI, H.; NAKAMURA, Y. \& WHEAT, R.W. - Serological cross-reactivity between Sporothrix schenckii and various unrelated fungi. Mycopathologia (Den Haag), 73: 65-68, 1981.

16. IWATSU, T.; MIYAJI, M.; TAGUCHI, H. \& OKAMOTO, S. - Evaluation of skin test for chromoblastomycosis using antigens prepared from culture filtrates of Fonsecaea pedrosoi, Phialophora verrucosa, Wangiella dermatitidis and Exophiala jeanselmei. Mycophatologia (Den Haag), 77: 59-64, 1982.

17. LACAZ, C.S; PORTO, E.; MARTINS, J.E.C.; HEINS-VACCARI, E.M. \& MELO, N.T. - Cromoblastomicose. In: Sarvier, 2002. p. 441-458. Tratado de Micologia médica Lacaz. São Paulo,

18. LINNET, K. - A review on the methodology for assessing diagnostic tests. Clin. Chem., 34: 1379-1386, 1988 .

19. LOWRY, D.H.; ROSEBROUGH, N.J.; FARR, S.L. \& RANDALL, R.J. - Protein measurement with the folin phenol reagent. J. biol. Chem., 193: 265-275, 1951.

20. McKINNEY, M.M. \& PARKINSON, A. - A simple non-chromatographic procedure to purify immunoglobulins from serum and ascites fluid. J. immunol. Meth., 96: 271278, 1987.

21. MIER, T.; NAVARRO, H. \& TORIELLO, C. - Relaciones inmunológicas entre Phialophora verrucosa, Fonsecaea pedrosoi, F. compacta, Cladosporium carrionii, y Wangiella dermatitidis a través de sus exoantígenos. Rev. mex. Micol., 6: 273280, 1990.

22. MINOTTO, R.; BERNARDI, C.D.; MALLMANN, L.F.; EDELWEISS, M.I. \& SCROFERNEKER, M.L. - Chromoblastomycosis: a review of 100 cases in the state of Rio Grande do Sul, Brazil. J. Amer. Acad. Derm., 44: 585-592, 2001.
23. NICOLASEN, L. \& SWATEK, F.E. - Some studies of exoantigens for the identification of the causative agents of chromoblastomycosis. Pan Amer. Hlth. Org. Scient. Publ., 396: $259-264,1980$.

24. OLIVEIRA, L.G. - Alguns aspectos imunológicos da cromomicose. Belo Horizonte, 1966. (Tese de doutoramento - Faculdade de Odontologia da Universidade Federal de Minas Gerais).

25. PEDROZO E SILVA, M.C. - Estudo clínico e epidemiológico da cromoblastomicose no estado do Maranhão, Brasil. São Luís, 1998. (Dissertação de mestrado Universidade Federal do Maranhão).

26. ROMERO, H.; GUEDEZ, E. \& MAGALDI, S. - Evaluation of immunoprecipitation techniques in chromoblastomycosis. J. Mycol. méd., 6: 83-87, 1996.

27. ROMERO, H.; FERRARA, G.; PEREZ-BLANCO, M. \& CONTRERAS, I. - An ELISA test for the serodiagnosis of chromoblastomycosis caused by Cladophialophora carrionii. J. Mycol. méd., 9: 210-213, 1999.

28. SILVA, D. B. - Micose de Lane (cromomicose ou cromoblastomicose). Aspecto atual do tema. Belém, 1955. (Tese de cátedra - Faculdade de Medicina e Cirurgia do Pará)

29. SILVA, J.P.; SOUZA, W. \& ROZENTAL, S. - Chromoblastomycosis: a retrospective study of 325 cases on Amazonic Region (Brazil). Mycophatologia (Den Haag), 143: $171-175,1999$.

30. TELLES FILHO, F.Q. - Contribuição aos aspectos micológicos, eco-epidemiológicos, clínicos e terapêuticos da cromoblastomicose. São Paulo, 1999. (Tese de doutoramento - Faculdade de Medicina da Universidade de São Paulo).

31. VIDAL, M.S.M.; MELO, N.T.; GARCIA, N.M. et al. - Paracoccidioides brasiliensis. A mycologic and immunochemical study of a sample isolated from an armadillo (Dasipus novencinctus). Rev. Inst. Med. trop. S. Paulo, 37: 43-49, 1995.

32. VILLALBA, E. - Detection of antibodies in the sera of patients with chromoblastomycosis by counter immunoelectrophoresis. I. Preliminary results. J. med. vet. Mycol., 26: 73-74, 1988.

33. VILLALBA, E. \& YEGRES, J.F. - Detection of circulating antibodies in patients affected by chromoblastomycosis by Cladosporium carrionii using double immunodiffusion. Mycopathologia (Den Haag), 102: 17-19, 1988.

Received: 4 June 2003

Accepted: 23 October 2003 